\title{
Exergy analysis of a spark ignition engine for different crankshaft speeds
}

\section{Farklı krank mili hızları için buji ateşlemeli bir motorun ekserji analizi}

\author{
Bülent ÖZDALYAN ${ }^{1}$ (D) , Cüneyt UYSAL ${ }^{2 *}$ (D) ${ }^{\text {Hüseyin KURT }}{ }^{3}$ (D)
}

\begin{abstract}
${ }^{1}$ Mechanical Engineering Department, Faculty of Engineering and Architecture, Mus Alparslan University, Mus, Turkey. b.ozdalyan@alparslan.edu.tr

${ }^{2}$ Automotive Technologies Program, TOBB Vocational School of Technical Sciences, Karabuk University, Karabuk, Turkey. cuneytuysal@karabuk.edu.tr
\end{abstract}

${ }^{3}$ Mechanical Engineering Department, Faculty of Engineering and Architecture, Necmettin Erbakan University, Konya, Turkey. huseyinkurt@konya.edu.tr

Received/Geliş Tarihi: 18.12.2017 Accepted/Kabul Tarihi: 03.10.2018

doi: $10.5505 /$ pajes.2018.81593

* Corresponding author/Yazıșllan Yazar Research Article/Araștırma Makalesi

\begin{abstract}
In this study, a spark ignition (SI) engine performance is exergetically investigated for different crankshaft speeds. The test engine is VSG413 SI type engine fueled with 95 octane gasoline. The test engine has 1.3 l volume, four stroke, four cylinder, $45 \mathrm{~kW}$ maximum power capacity and $98 \mathrm{Nm}$ maximum torque capacity. The experiments are realized under fully loaded test conditions. The crankshaft speed is changed between $1200 \mathrm{rpm}$ and $5000 \mathrm{rpm}$. In the calculations, actual operating data obtained by experiments are used. It is found that maximum energy and exergy efficiencies are obtained at crankshaft speed of $2500 \mathrm{rpm}$, which are $29.78 \%$ and $27.77 \%$, respectively. Entropy generation rate increases with increase in crankshaft speed and ranged from 0.059 $\mathrm{kW} / \mathrm{K}$ to $0.253 \mathrm{~kW} / \mathrm{K}$ for all study.
\end{abstract}

Keywords: Spark ignition engine, Exergy analysis, Exergy efficiency, Exergy destruction

\section{Introduction}

In recent years, exergy analysis method has been widely used to design and simulate various thermal systems and to assess their performances. In this regard, exergy analysis method can be applied to various types of engines for determination of efficiencies and losses $[1,2]$. The exergy analysis is based on the second law of thermodynamics together with the conservation of mass and the first law of thermodynamics. Exergy analysis helps designer or engineer to determine which processes or components are responsible for the most significant exergy losses and exergy destructions (irreversibilities). By this way, the exergy losses and exergy destructions are defined for processes and components of any thermal system and one can focus on these process and components to improve the system performance and efficiency. Therefore, the exergy analysis is a very effective tool in the analysis of energy systems [3].

For analysis of real engine cycles to determine their performances and to understand the effect of various operating conditions on their efficiencies, thermodynamic models of the real engine cycles are used. However, it has been understood that conventional energy balance analysis, which is necessary for modeling the engine processes, often fails in the accurately determination of system performance and in the performance improvement studies. In order to analyze engine performance, the second-law analysis must be applied. That is evaluation of the inefficiencies related with the various processes. The key concept is exergy for the second-law analysis. The available energy definition of a material means its potential to do work.
Öz

Bu çalıșmada, buji ateșlemeli bir motorun performansı farklı krank mili hızları için ekserjetik olarak incelenmektedir. Test motoru 95 oktan benzin yakıtlı VSG413 SI türü motordur. Test motoru 1.3 l hacim, dört strok, dört silindir, 45 kW'llk maksimum güç kapasitesi ve 98 Nm'lik maksimum tork kapasitesine sahiptir. Deneyler tam yük test koşulları altında gerçekleștirilmisțtir. Krank mili hızı 1200 d/d ve 5000 d/d aralığında değiştirilmiştir. Hesaplamalarda, deneylerden elde edilen gerçek çalısma verileri kullanılmıștır. \%29.78'lik maksimum enerji verimi ve \%27.77'lik maksimum ekserji veriminin 2500 rpm'lik krank mili hızında elde edildiği tespit edilmiștir. Entropi üretimi krank mili hızının artmasıyla artmaktadır ve bütün çalıșma boyunca $0.059 \mathrm{~kW} / \mathrm{K}$ ile $0.253 \mathrm{~kW} / \mathrm{K}$ aralığında değișmektedir.

Anahtar Kelimeler: Buji ateșlemeli motor, Ekserji analizi, Ekserji verimi, Ekserji yıkımı

Exergy efficiency of an internal combustion engine fueled with high-oleic methyl ester increases with decreasing dead state temperature [4]. The optimum operation speed of a gasoline engine is determined to be $2580 \mathrm{rpm}$ in the sense of energy and exergy concepts when the engine performed in various engine speeds [5]. Internal combustion engine with homogeneous charge compression ignition (HCCI) has the highest energy and exergy efficiency compared to engines with conventional diesel combustion (CDC) and reactivity controlled compression ignition (RCCI) [6]. The energy and exergy analyses of a wet ethanol HCCI engine revealed that the heat transfer process realized in the fuel vaporizer and heat exchanger and the catalytic converter are responsible for $4.39 \%$ and $4.08 \%$ of total exergy destruction of overall system, respectively [7]. Energy and exergy analyses of a four-cylinder, four stroke SI engine fueled with 91, 93 and 95.3 octane fuels and operated under different torques and crankshaft speeds showed that 91 octane fuel has the best energy and exergy performance compared to other investigated fuels and the combustion process is the most important parameter in the system efficiency [8]. The engines fueled with some biodiesels display same energetic performance with ones fueled with petroleum diesel and their exergetic performance parameters show similar trend with corresponding energetic parameters [9]. In evaluation of the optimal loads of a compression ignition engine using local biofuels such as cotton seed oil and palm oil, the exergy and gas emission analyses are very effective tool [10]. Exergy efficiency of a stationary turbocharged diesel engine of 19 MW including compressor, turbine, cooler and radiator is 
approximately $40.5 \%$ [11]. However, the maximum exergy efficiency of turbocharged diesel engine with four-cylinder and four-stroke is about obtained to be $30 \%$, except stationary diesel engines. Higher exergy efficiencies can be obtained for engines at lower crankshaft speeds ranged between 1140 and $2200 \mathrm{rpm}$ [12]. Therefore, it can be said that the irreversibilities occurred during compression, expansion and combustion processes on engine cycle are considerable affected with design and operation conditions of engine [13]. In the engine cycle processes, energy and exergy values of heat rejection increase with increasing engine speed [14]. In a single cylinder, water cooled SI engine fueled with LPG, the fuel consumption increases with decrease in the bore-to-stroke ratio increases, while the exergy destruction is minimized [15]. Exergy based optimal control strategy leads to an average of $6.7 \%$ fuel saving and $8.3 \%$ exergy saving compared to commonly used energy based combustion control [16]. Exergy analysis revealed that the lowest exergy destruction fraction is at the stoichiometric combustion [17]. In a Deutz engine fueled with dual fuel (diesel+hydrogen), exergy efficiency decreases with increase in gas-fuel ratio [18]. Diesel, ethanol and pongamia piñata methyl ester blend usage as fuel in internal combustion engines increases exergy efficiency and decreases exergy destruction and entropy production rate [19].

The present study deals with exergy analyses for the performance evaluation of the SI engine. The exergy values of leaving and entering streams such as lubrication oil, cooling water and exhaust gases are separately investigated for different crankshaft speeds. Separately investigation of lubrication oil and cooling water is important for determination of lifetime of lubrication oil. The effect of crankshaft speed on exergy efficiency of the test engine is determined.

\section{Experimental setup}

A spark ignition (SI) engine performance was exergetically investigated for different crankshaft speeds. The engine which is Ford VSG413 SI engine fueled with 95 octane gasoline has 1.3 liter volume, four stroke, four cylinder, $45 \mathrm{~kW}$ maximum power capacity and $98 \mathrm{Nm}$ maximum torque capacity.

The experimental setup, shown in Figure 1, consists of test engine, dynamometer, exhaust calorimeter, temperature indicators and flow meters of fuel, engine coolant, exhaust calorimeter coolant, lubrication oil and intake air. The test engine specifications, lubrication oil and fuel properties were given in Table 1-3, respectively.

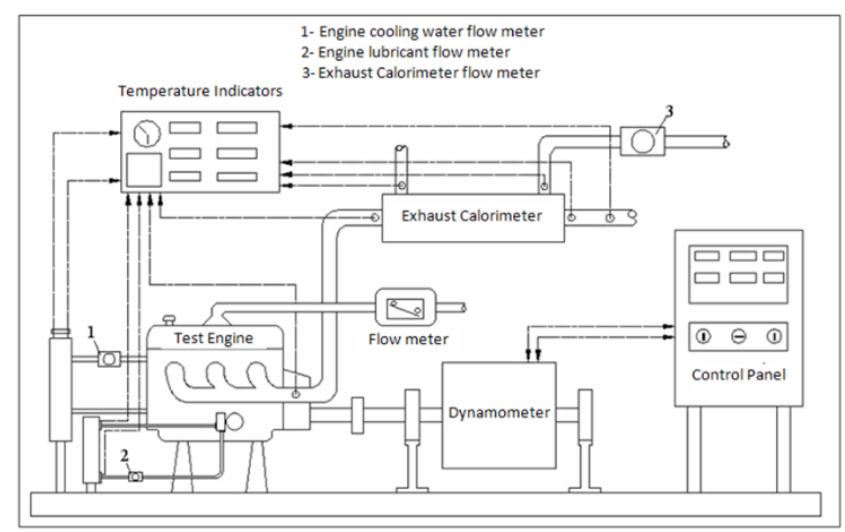

Figure 1: Schematic diagram for experimental setup.
Table 1: The test engine specifications.

\begin{tabular}{cc}
\hline Items & Engine \\
\hline Mark & Ford VSG413 CFi \\
Engine Type & Four stroke, Four cylinder \\
Maximum Power & $43 \mathrm{~kW}$ at $5000(\mathrm{rpm})$ \\
Maximum Torque & $98 \mathrm{Nm}$ at $2500(\mathrm{rpm})$ \\
Cylinder Bore & $73.96 \mathrm{~mm}$ \\
Stroke & $75.48 \mathrm{~mm}$ \\
Total Cylinder Volume & $1297 \mathrm{~cm}^{3}$ \\
Compression Ratio & $8.8: 1$ \\
Fuel System & Single point injected \\
Firing Order & $1-2-4-3$ \\
Compression Pressure & $13-16 \mathrm{bar}$ \\
Cooling System & Water cooled \\
\hline Valve Timing & \\
\hline Intake valve opens & $12^{\circ}$ BTDC \\
Intake valve closes & $48^{\circ}$ ABDC \\
Exhaust valve opens & $47^{\circ}$ BTDC \\
Exhaust valve closes & $13^{\circ}$ ATDC \\
\hline
\end{tabular}

Table 2: The engine lubrication oil specifications.

\begin{tabular}{ccc}
\hline \multicolumn{3}{c}{ Castrol GTX 20 W50 } \\
\hline Specification & Unit & Typical value \\
Density (at $\left.15^{\circ} \mathrm{C}\right)$ & $\mathrm{g} / \mathrm{cm}^{3}$ & 0.8860 \\
Density $\left(\right.$ at $\left.100^{\circ} \mathrm{C}\right)$ & $\mathrm{g} / \mathrm{cm}^{3}$ & 0.8180 \\
Viscosity $\left(\right.$ at $\left.40^{\circ} \mathrm{C}\right)$ & $\mathrm{cSt}$ & 158.9 \\
Viscosity $\left(\right.$ at $\left.100^{\circ} \mathrm{C}\right)$ & $\mathrm{cSt}$ & 18 \\
Viscosity (at $\left.-15^{\circ} \mathrm{C}\right)$ & $\mathrm{cP}$ & 9300 \\
Flame Point $(\mathrm{PMCC})$ & ${ }^{\circ} \mathrm{C}$ & 198 \\
Pour Point & ${ }^{\circ} \mathrm{C}$ & -29 \\
\hline
\end{tabular}

Table 3: The engine fuel specifications.

\begin{tabular}{ccc}
\hline Gasoline & & \\
\hline Specification & Unit & Typical value \\
Typical formula & -- & $\mathrm{C}_{8} \mathrm{H}_{16}$ \\
Density (at 15 ${ }^{\circ} \mathrm{C}$ ) & $\mathrm{kg} / \mathrm{m}^{3}$ & 764.9 \\
Stoichiometric air/fuel ratio & -- & 14.9 \\
Research octane number & -- & 95 \\
Lower heating value & $\mathrm{kJ} / \mathrm{kg}$ & 43920 \\
Laminar flame speed & $\mathrm{m} / \mathrm{s}$ & 0.36 \\
Auto-ignition temperature & ${ }^{\circ} \mathrm{C}$ & 257 \\
\hline
\end{tabular}

The exhaust calorimeter was placed between the exhaust manifold and the silencer. To measure the volumetric flow rate of calorimeter cooling water, KDG Mobrey 2000 was used, which has measurement range between $100 \mathrm{~L} / \mathrm{h}$ to $980 \mathrm{~L} / \mathrm{h}$ with $20 \mathrm{~L} / \mathrm{h}$ sensitivity. The temperatures were measured with thermocouples 12 channeled Elimko 6000 which have the sensitivity of $1^{\circ} \mathrm{C}$. The engine cooling water flow rate was measured with GPI flow meter which has $0.1 \mathrm{~L} / \mathrm{min}$ sensitivity and horizontally placed the front of engine cooling water input. The engine oil flow rate was also measured with the Macnaught flow meter which has measurement range between $2 \mathrm{~L} / \mathrm{min}$ to $30 \mathrm{~L} / \mathrm{min}$ with $0.01 \mathrm{~L} / \mathrm{min}$ sensitivity.

Before starting the experiment, engine oil filter and oil were changed and all circuit connections were controlled. The measurements were realized for the steady-state and fully loaded conditions of test engine. The engine crankshaft speed was changed between $1200 \mathrm{rpm}$ to $5000 \mathrm{rpm}$. The volumetric flow rates and the temperatures of cooling waters, lubrication oil and exhaust gases were measured at constant crankshaft speed. Moreover, the engine block and dead-state temperatures were measured. A conic edge orifice meter was used to measure the intake air flow rate. 
The exhaust calorimeter was placed between the exhaust manifold and the silencer. KDG Mobrey 2000 was used to measure the volumetric flow rate of calorimeter cooling water, which has measurement range between 100 to $980 \mathrm{~L} / \mathrm{h}$ with $20 \mathrm{~L} / \mathrm{h}$ sensitivity. The temperatures were measured with thermocouples 12 channeled Elimko 6000 which have the sensitivity of $1^{\circ} \mathrm{C}$. The engine cooling water flow rate was measured with GPI flow meter which has $0.1 \mathrm{~L} / \mathrm{min}$ sensitivity and horizontally placed the front of engine cooling water input. The engine oil flow rate was also measured with the Macnaught flow meter which has measurement range between 2 to $30 \mathrm{~L} / \mathrm{min}$ with $0.01 \mathrm{~L} / \mathrm{min}$ sensitivity. The experimental results obtained by the test engine are presented in Table 4 .

\section{Mathematical model}

In the determination of an engine characteristics; torque, effective power and specific fuel consumption are used. The torque values of the test engine obtained with measurements for different crankshaft speeds are shown in Table 4 . The effective power $\left(P_{e}\right)$ of the test engine can be defined as follows,

$$
P_{e}=\frac{T n}{9549}
$$

where $n[\mathrm{rpm}]$ is the crankshaft speed and T [Nm] is torque. The specific fuel consumption (sfc) of the test engine can be calculated by following formula,

$$
s f c=\frac{3600 \dot{m}_{\text {fuel }}}{P_{e}}
$$

where $\dot{m}$ is mass flow rate of consumed fuel. By this way, performance characteristics values obtained for the test engine are illustrated in Figure 2.

Figure 2 shows that the torque value increases until crankshaft speed of $3000 \mathrm{rpm}$ and then decreases. On the contrary to torque, the specific fuel consumption decreases until crankshaft speed of $3000 \mathrm{rpm}$ and then increases. The minimum specific fuel consumption and the maximum torque values are obtained at $3000 \mathrm{rpm}$. The effective power increases with increasing crankshaft speed.

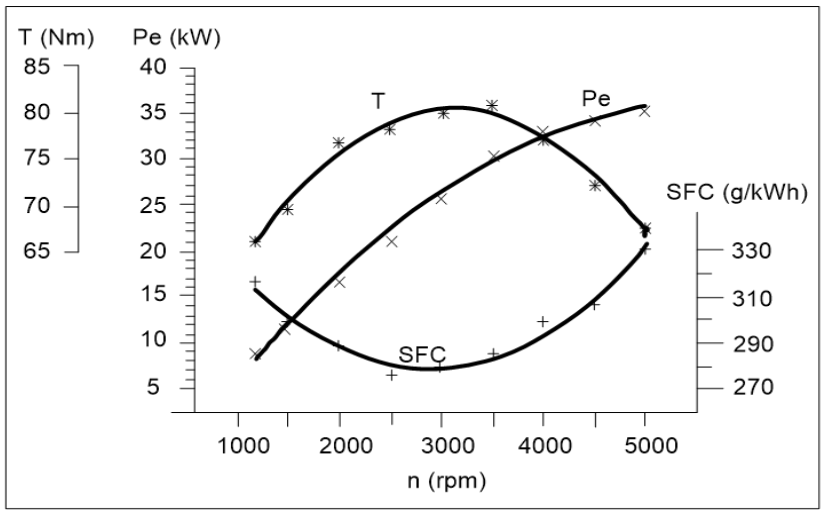

Figure 2: Characteristics of the test engine.

\section{Exergy analysis}

Mass and energy balances for a control volume of a steady-state open thermodynamic system can be expressed by the following Equations (3) and (4), respectively.

$$
\begin{gathered}
\sum \dot{m}_{\text {in }}=\sum \dot{m}_{\text {out }} \\
\dot{Q}-\dot{W}=\sum \dot{m}_{\text {out }} h_{\text {out }}-\sum \dot{m}_{\text {in }} h_{\text {in }}
\end{gathered}
$$

where the subscripts in and out denote inlet and outlet states, respectively. In addition, $\dot{m}[\mathrm{~kg} / \mathrm{s}]$ is mass flow rate, $\dot{Q}$ [W] is heat transfer rate and $\mathrm{h}$ is specific enthalpy. In addition, the exergy balance of the test engine can be expresses as follows;

$$
E \dot{x}_{Q}+E \dot{x}_{W}+E \dot{x}_{\text {dest }}=\sum \dot{m}_{\text {in }} \varepsilon_{\text {in }}-\sum \dot{m}_{\text {out }} \varepsilon_{\text {out }}
$$

The first term on the left side of above equation expresses the exergy rate associated with heat transfer, while the second and third ones express the exergy rate associated with work and the exergy destruction, respectively.

Table 4: The test engine measurements.

\begin{tabular}{cccccccccccc}
\hline $\begin{array}{c}\mathrm{n} \\
(\mathrm{rpm})\end{array}$ & $\begin{array}{c}\mathrm{T} \\
(\mathrm{Nm})\end{array}$ & $\begin{array}{c}\dot{m}_{\text {fulel }} \\
(\mathrm{kg} / \mathrm{s})\end{array}$ & $\begin{array}{c}\dot{m}_{c w} \\
(\mathrm{~kg} / \mathrm{s})\end{array}$ & $\begin{array}{c}\dot{m}_{l u b} \\
(\mathrm{~kg} / \mathrm{s})\end{array}$ & $\begin{array}{c}T_{c w, \text { in }} \\
(\mathrm{K})\end{array}$ & $\begin{array}{c}T_{c w, \text { out }} \\
(\mathrm{K})\end{array}$ & $\begin{array}{c}T_{l u b, \text { in }} \\
(\mathrm{K})\end{array}$ & $\begin{array}{c}T_{l u b, \text { out }} \\
(\mathrm{K})\end{array}$ & $\begin{array}{c}T_{e x} \\
(\mathrm{~K})\end{array}$ & $\begin{array}{c}T_{e b} \\
(\mathrm{~K})\end{array}$ & $\begin{array}{c}T_{0} \\
(\mathrm{~K})\end{array}$ \\
\hline 1200 & 65.8 & 0.000722 & 0.0217 & 0.0459 & 301 & 365 & 354 & 379 & 856 & 365 & 310 \\
1500 & 70.1 & 0.000911 & 0.0250 & 0.0492 & 302 & 364 & 357 & 382 & 906 & 364 & 310 \\
2000 & 78.0 & 0.001308 & 0.0300 & 0.0525 & 306 & 364 & 360 & 384 & 953 & 366 & 311 \\
2500 & 79.5 & 0.001590 & 0.0350 & 0.0552 & 306 & 364 & 351 & 380 & 961 & 367 & 306 \\
3000 & 81.6 & 0.001981 & 0.0483 & 0.0559 & 306 & 366 & 339 & 359 & 966 & 365 & 306 \\
3500 & 82.3 & 0.002382 & 0.0633 & 0.0586 & 309 & 366 & 361 & 380 & 1033 & 367 & 306 \\
4000 & 78.2 & 0.002707 & 0.0767 & 0.0612 & 311 & 365 & 362 & 387 & 1038 & 366 & 310 \\
4500 & 72.6 & 0.002897 & 0.0933 & 0.0672 & 313 & 365 & 362 & 391 & 1071 & 368 & 313 \\
5000 & 67.5 & 0.003222 & 0.1033 & 0.0701 & 315 & 365 & 360 & 391 & 1101 & 369 & 315 \\
\hline
\end{tabular}


In Equation 4, $\dot{Q}$ represents the heat transfer rate removed from investigated state or stream and released to environment rejected to the environment and can be written as follows:

$$
\dot{Q}=\dot{m}_{\text {fuel }} H_{u}-\dot{m}_{e x} \Delta h_{e x}-\dot{W}
$$

where $\dot{m}_{e x}$ is the total mass of exhaust gas species. According to Equation (3), the mass of fuel and air supplied to the test engine should be equal to the total mass of exhaust gas species. Also, $\Delta h_{e x}$ is defined as $\left(h-h_{0}\right)$, where $h$ and $h_{0}$ are the enthalpies of exhaust gas species at measured exhaust temperatures and environmental temperatures, respectively, and calculated from the sum of these enthalpy differences for all exhaust gas species. The exergy rate associated with heat transfer is written as follows;

$$
E \dot{x}_{Q}=\sum\left(1-\frac{T_{0}}{T}\right) \dot{Q}
$$

where $T_{0}[\mathrm{~K}]$ is environmental temperature $(\mathrm{K})$ which is also called as reference or dead-state temperature and is the temperature of any state or stream.

The energy value of work of a control volume is equal to its exergy value. Therefore, the work [W] and exergy rate [W] associated with work is calculated by using following equation;

$$
E \dot{x}_{W}=\dot{W}=\omega \mathrm{T}
$$

where $\omega[\mathrm{rad} / \mathrm{s}]$ is angular velocity. Angular velocity is calculated with Equation (9) as radians per second.

$$
\omega=\frac{\pi n}{30}
$$

The second term on the right side of Equation 4 indicates the energy of any stream entering to control volume. For this study, this term is represented the fuel stream entering to the test engine. The energy value of fuel entering to the test engine can be found by using following equation,

$$
\dot{E}_{\text {fuel }}=\dot{m}_{\text {fuel }} H_{u}
$$

where $H_{u}[\mathrm{~kJ} / \mathrm{kg}]$ is the lower heating value of the fuel. In a similar manner, the first term on the right side of Equation 5 represents the exergy of any stream entering to control volume. This term is represented by the fuel stream entering to the test engine and the exergy value of fuel is written as follows,

$$
E \dot{x}_{\text {fuel }}=\dot{m}_{\text {fuel }} \varepsilon_{\text {fuel }}
$$

where $\varepsilon_{\text {fuel }}[\mathrm{kJ} / \mathrm{kg}]$ expresses the specific exergy of fuel and can be found as follows:

$$
\varepsilon_{\text {fuel }}=H_{u} \varphi
$$

where $\varphi[-]$ is the chemical exergy factor. The chemical exergy factor is found by Equation (13), [20].

$$
\begin{aligned}
\varphi=1.0401+ & 0.1728 \frac{h}{c}+0.0432 \frac{o}{c} \\
& +0.2169 \frac{\alpha}{c}\left(1-2.0628 \frac{h}{c}\right)
\end{aligned}
$$

where $h$ [\%], $c$ [\%], $o[\%]$ and $\alpha$ [\%]are the mass fractions of hydrogen, carbon, oxygen and sulphur in the fuel content, respectively. Mass fractions of elements were calculated by using the general formula of fuel.

The second term on the right side of Equation 5 represents the exergy value of any stream leaving from control volume. The exergy rate of exhaust gases leaving from the test engine is used for this term in this study. Exergy rate associated with exhaust gases consists of the sum of thermomechanical and chemical exergies as follows,

$$
E \dot{x}_{e x}=\sum \dot{m}_{i}\left(\varepsilon_{t h}+\varepsilon_{c h e m}\right)_{i}
$$

where $\dot{m}_{i}[\mathrm{~kg} / \mathrm{s}]$ is the mass flow rate of the exhaust gas components, $\varepsilon_{t h}[\mathrm{~kJ} / \mathrm{kg}]$ and $\varepsilon_{\text {chem }}[\mathrm{kJ} / \mathrm{kg}]$ are the specific thermomechanical and chemical exergies of the exhaust gas components, respectively. The thermomechanical exergy of exhaust gases can be written as follows,

$$
\varepsilon_{t h}=\left(h-h_{0}\right)-T_{0}\left(s-s_{0}\right)
$$

where $s[\mathrm{~kJ} / \mathrm{kgK}]$ and $s_{0}[\mathrm{~kJ} / \mathrm{kgK}]$ are the entropy values of exhaust gas components at measured exhaust and environmental temperatures, respectively. The chemical exergy of exhaust gases can be calculated by using following equation,

$$
\varepsilon_{\text {chem }}=R T_{0} \ln \frac{y}{y^{e}}
$$

where $R[\mathrm{~kJ} / \mathrm{kgK}]$ is the ideal gas constant, $y[\%]$ and $y^{e}[\%]$ are the molar fraction of the exhaust gas component and the definition of environment, respectively. $y^{e}[\%]$ value using in this study is shown in Table 5.

Table 5: Standard Air Properties $\left(\mathrm{P}_{0}=101.325 \mathrm{kPa}, \mathrm{T}_{0}=298 \mathrm{~K}\right)$ [21].

\begin{tabular}{cc}
\hline Component & Mole Fraction (\%) \\
\hline $\mathrm{N}_{2}$ & 75.67 \\
$\mathrm{O}_{2}$ & 20.35 \\
$\mathrm{CO}_{2}$ & 0.0345 \\
$\mathrm{H}_{2} \mathrm{O}$ & 3.03 \\
$\mathrm{CO}$ & 0.0007 \\
$\mathrm{SO}_{2}$ & 0.0002 \\
$\mathrm{H}_{2}$ & 0.00005 \\
Other & 0.91455 \\
\hline
\end{tabular}


The molar fraction of the exhaust gas component is found by using the following reaction equations. In the cases of $\lambda>1$, Equation (17) is used [22], while Equation (18) which is developed by using Equation (17) is used in the cases of $\lambda<1$ as chemical reaction to determine the molar fraction of the exhaust gas component. Thus, the molar fractions of components are determined by using measured mass flow rates of fuel and air through mass balance equation.

$$
\begin{gathered}
C_{\alpha} H_{\beta}+\lambda\left(\alpha+\frac{\beta}{4}\right)\left(O_{2}+3.76 N_{2}\right) \rightarrow \alpha C O_{2} \\
+\frac{\beta}{2} H_{2} O+3.76 \lambda\left(\alpha+\frac{\beta}{4}\right) N_{2}+(\lambda-1)\left(\alpha+\frac{\beta}{4}\right) O_{2} \\
C_{\alpha} H_{\beta}+\lambda\left(\alpha+\frac{\beta}{4}\right)\left(O_{2}+3.76 N_{2}\right) \rightarrow \\
{\left[\alpha-2(1-\lambda)\left(\alpha+\frac{\beta}{4}\right)\right] C O_{2}+\frac{\beta}{2} H_{2} O} \\
+3.76 \lambda\left(\alpha+\frac{\beta}{4}\right) N_{2}+2(1-\lambda)\left(\alpha+\frac{\beta}{4}\right) C O
\end{gathered}
$$

where $\lambda$ is the excess air coefficient. The third term on the left side of Equation 5 is exergy destruction of control volume. Exergy destruction rate can be easily found by using exergy balance equation. Entropy production rate can be expressed as the exergy destruction per the environmental temperature. Therefore, it can be written as follows:

$$
\dot{S}=\left(E \dot{x}_{\text {dest }}\right) /\left(T_{0}\right)
$$

In the thermodynamically performance evaluation of test engine, the thermal and exergy efficiencies of test engine are used. The thermal efficiency of the test engine is defined as the ratio of the work rate to the fuel energy input rate and can be written as follows,

$$
\eta=(\dot{W}) /\left(\dot{E}_{\text {fuel }}\right)
$$

The exergy efficiency is defined for the test engine as follows,

$$
\psi=\left(E \dot{x}_{W}\right) /\left(E \dot{x}_{i n}\right)
$$

\section{Results and discussion}

Exergy analysis of a spark ignition (SI) engine is performed for different crankshaft speeds in the light of data obtained from experimental measurement, which is presented in Table 4. Exergy values of all leaving and entering streams related with the engine are separately defined. Especially, the exergy values removed from the engine by means of cooling water and lubrication oil are separately defined and calculated.

The input exergy rate of the test engine is related with the fuel supply and calculated with Equation 11 . The obtained results for input exergy rate of the test engine are illustrated in Figure 3. Input exergy rate of the test engine increases with increasing crankshaft speed. This is due to fuel consumption increases with increase in crankshaft speed. Input exergy rate of the test engine ranged from $34.1 \mathrm{~kW}$ to $151.76 \mathrm{~kW}$.

In this study, the components of exergy rate associated with heat transfer are heat transfers from the test engine to cooling water, to lubrication oil and to environment. The values of this exergy rate streams associated with heat transfer can be separately calculated with Equation 7 and the obtained results are illustrated in Figure 4-6.

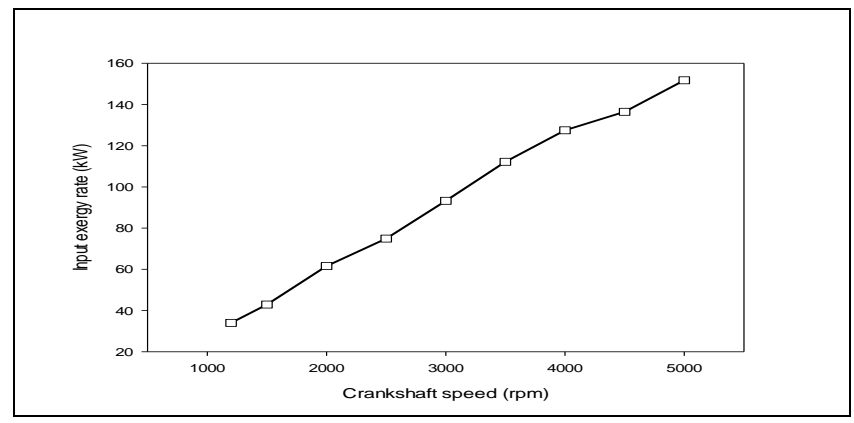

Figure 3: Variation of input exergy rate with crankshaft speed.

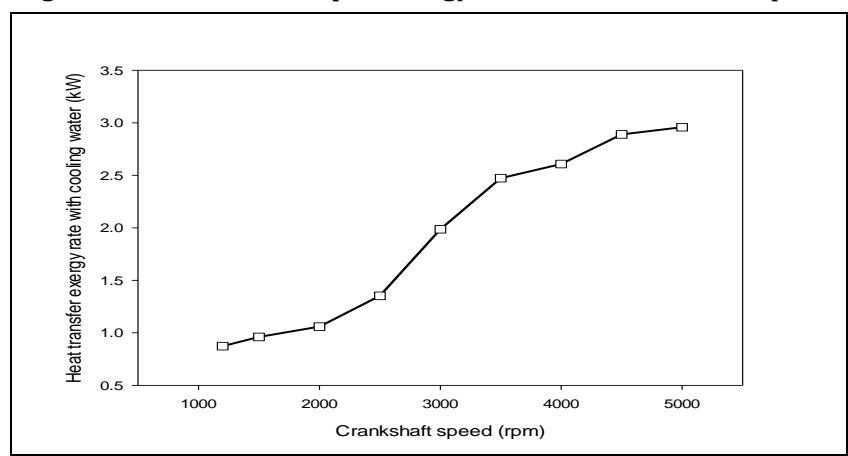

Figure 4: Variation of exergy rate associated with heat removed from the test engine through cooling water with crankshaft speed.

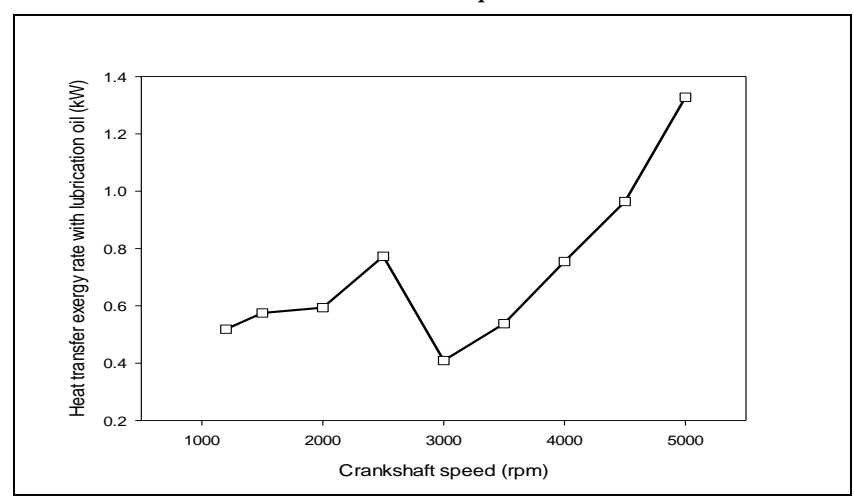

Figure 5: Variation of exergy rate associated with heat removed from the test engine through lubrication oil with crankshaft speed.

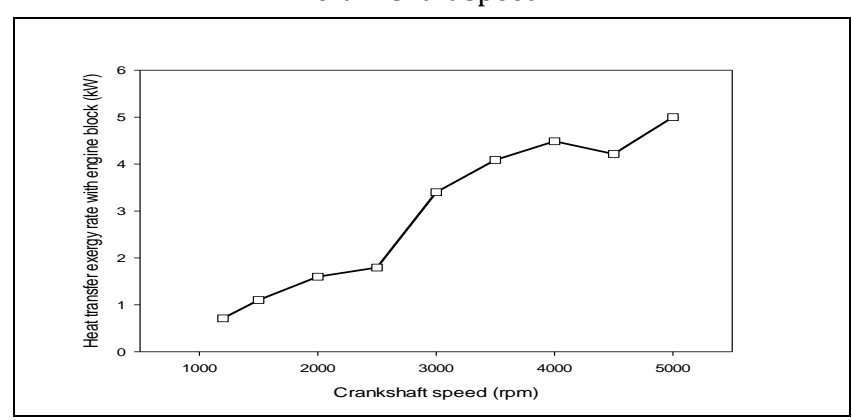

Figure 6: Variation of exergy rate associated with heat transferred from the engine block to environment with crankshaft speed. 
Figure 4 shows that the exergy rate related with heat removed from the test engine through cooling water increases with increase in crankshaft speed. An extreme increment is observed between $2500 \mathrm{rpm}$ and $3500 \mathrm{rpm}$. The exergy rate related with heat removed through cooling water is $1.3521 \mathrm{~kW}$ at $2500 \mathrm{rpm}$, while it is $1.9872 \mathrm{~kW}$ and $2.4737 \mathrm{~kW}$ at $3000 \mathrm{rpm}$ and 3500 rpm, respectively.

The exergy rate associated with heat removed through lubrication oil is shown in Figure 5. This parameter is very important for determination of lifetime of lubrication oil. Decreasing in heat transferred to lubrication oil protects the color change and dilution of lubrication oil. This increases lifetime of lubrication oil.

As can be seen from Figure 5, the exergy rate associated with heat removed through lubrication oil slightly increases up to the crankshaft speed of $2500 \mathrm{rpm}$. After $2500 \mathrm{rpm}$, it decreases and obtains its minimum value at the crankshaft speed of 3000 $\mathrm{rpm}$. However, it extremely increases after the crankshaft speed of $3000 \mathrm{rpm}$. The exergy rate associated with heat removed through lubrication oil increases from $0.4093 \mathrm{~kW}$ to $1.3281 \mathrm{~kW}$ between 3000 and $5000 \mathrm{rpm}$. Whereas, it is 0.7733 $\mathrm{kW}$ at $2500 \mathrm{rpm}$.

Figure 6 shows the exergy rate related with heat transfer from engine block to environment. Heat transfer exergy rate increases with increasing crankshaft speed. Exergy rate of heat transferred from engine block to environment is $0.7127 \mathrm{~kW}$ at $1200 \mathrm{rpm}$, it is $5.0014 \mathrm{~kW}$ at $5000 \mathrm{rpm}$.

It is found from Figures 4-6 that the proportion of the exergy rate associated with heat transferred from engine block to environment on total exergy rate associated with heat transfer is higher compared to that of related ones with cooling water and lubrication oil. It is followed by the proportions of cooling water and lubrication oil, respectively. This means that to enhance the engine performance, the designer or engineer should firstly focus on to reduce heat amount transferred from the engine to environment.

The components of exhaust gases can be found by using Equation 17 and 18 and the exergy rate of exhaust gases can be calculated by using Equation 14. The results obtained for exhaust exergy rate are illustrated in Figure 7. The value of exergy rate of exhaust gases increases almost linearly with increase in crankshaft speed. It is ranged between $5.11 \mathrm{~kW}$ and $27.27 \mathrm{~kW}$ for $1200 \mathrm{rpm}$ and $5000 \mathrm{rpm}$. However, a deceleration is observed between $2500 \mathrm{rpm}$ and $3000 \mathrm{rpm}$.

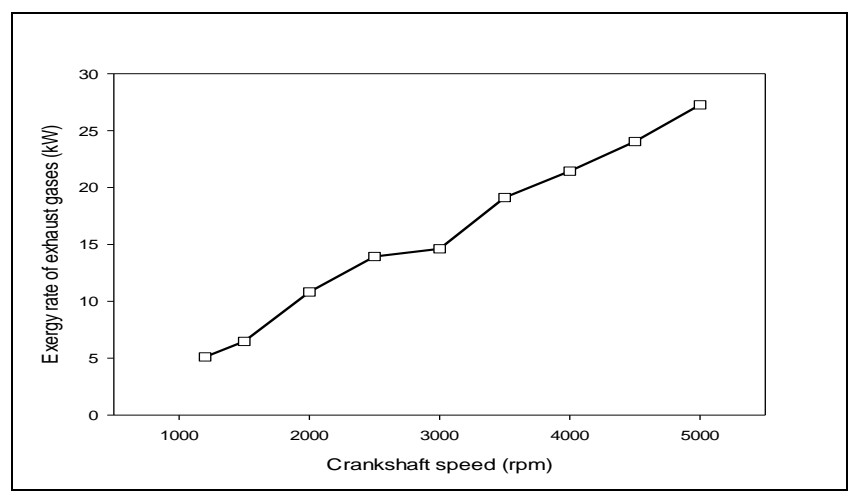

Figure 7: Variation of exergy rate of exhaust gases with crankshaft speed.

The exergy rate associated with work produced by test engine is calculated by using Equation 8 and the results obtained are shown in Figure 8. The exergy rate associated with work almost linearly increase between crankshaft speed of $1200 \mathrm{rpm}$ and $3500 \mathrm{rpm}$. After $3500 \mathrm{rpm}$, the increment in the exergy rate associated with work decelerates. The exergy rate associated with work ranges between $8.26 \mathrm{~kW}$ and $35.33 \mathrm{~kW}$.

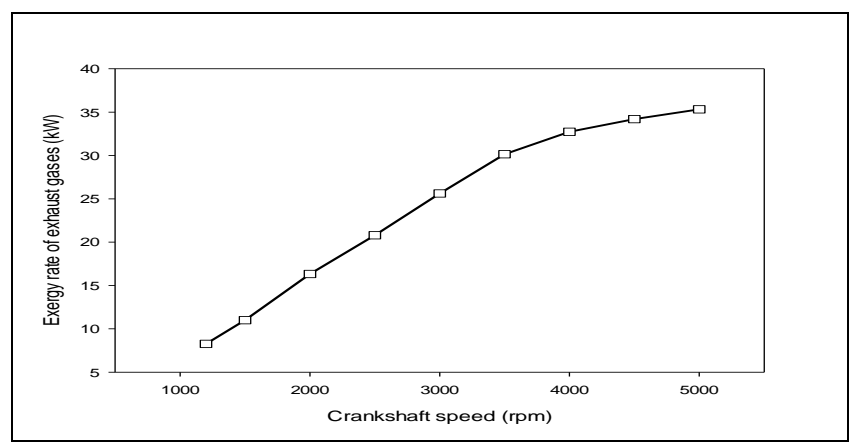

Figure 8: Variation of exergy rate associated with work with crankshaft speed.

The exergy destruction rate and the entropy production rate of the test engine is found by using Equation 5 and 19; respectively, and obtained results are shown in Figure 9 and 10, respectively. The exergy destruction rate and the entropy production rate of the test engine almost linearly increases with increasing crankshaft speed. The exergy destruction rate obtained for $1200 \mathrm{rpm}$ is $18.54 \mathrm{~kW}$, while it is $79.89 \mathrm{~kW}$ for $5000 \mathrm{rpm}$. In addition, the entropy production rate ranges between $0.0598 \mathrm{~kW} / \mathrm{K}$ and $0.2536 \mathrm{~kW} / \mathrm{K}$ for this study.

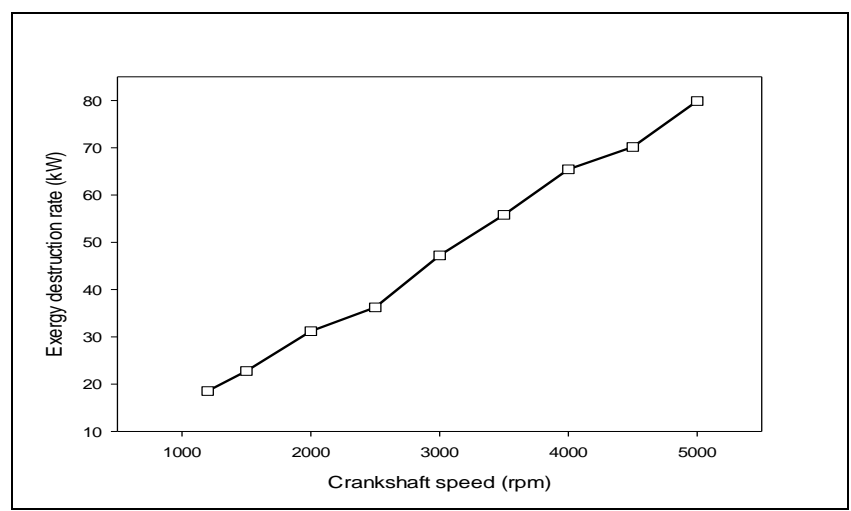

Figure 9: Variation of exergy destruction rate with crankshaft speed.

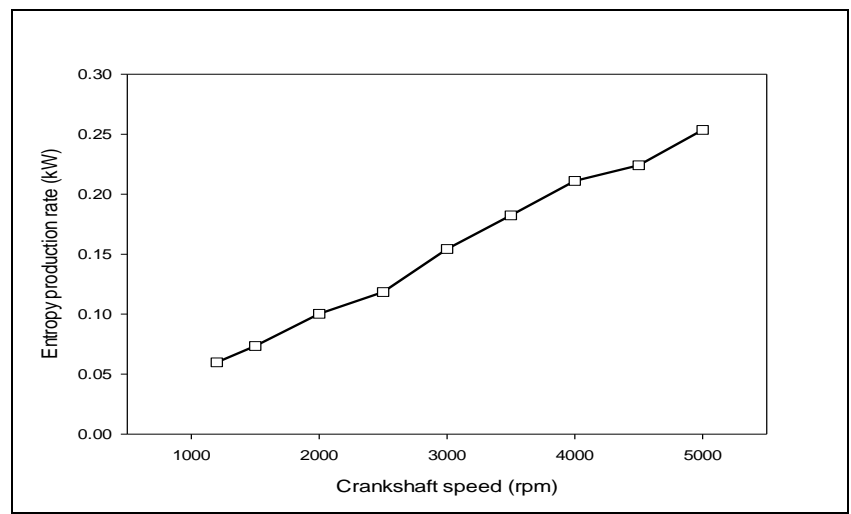

Figure 10: Variation of entropy production rate with crankshaft speed.

The thermal and exergy efficiencies of the test engine are calculated by using Equation 20 and 21, respectively. The 
variation of energy and exergy efficiencies of the test engine with crankshaft speed are illustrated in Figure 11.

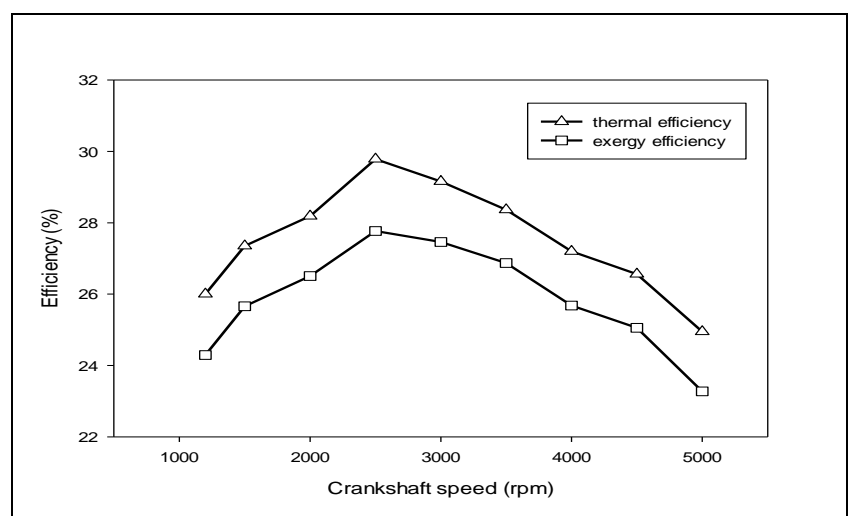

Figure 11: Variation of energy and exergy efficiencies with crankshaft speed.

As can be seen from Figure 11, energy efficiency of engine firstly increased with the increase in the crankshaft speed, and then decreased. The maximum energy efficiency of $29.78 \%$ is obtained at crankshaft speed of $2500 \mathrm{rpm}$. Moreover, during all tests, it is observed that the energy efficiency of the engine varied between $24.96 \%$ and $29.78 \%$. It is also observed that graphic of exergy efficiency is in same trend with that of energy efficiency, but as it is expected, exergy efficiency values are smaller than that of energy efficiency. During all the tests, exergy efficiency varied between $23.27 \%$ and $27.77 \%$. The maximum exergy efficiency is observed at crankshaft speed of $2500 \mathrm{rpm}$, and found to be $27.77 \%$.

\section{Conclusions}

In this study, the SI engine performance is exergetically investigated for different crankshaft speeds. The exergy streams for cooling water and lubrication oil are separately investigated. The main conclusions may be listed as follows:

- The maximum energy and exergy efficiencies are observed at crankshaft speed of 2500 , rpm which are $29.78 \%$ and $27.77 \%$, respectively,

- Exergy destruction rate ranges from $18.53 \mathrm{~kW}$ to $79.89 \mathrm{~kW}$, while entropy production rate is in the range of $0.06 \mathrm{~kW} / \mathrm{K}$ to $0.256 \mathrm{~kW} / \mathrm{K}$,

- $\quad$ The exergy rate associated with heat transferred from engine block to environment has higher contribution to total exergy rate associated with heat transfer compared to that of cooling water and lubrication oil.

\section{References}

[1] Dincer I. "Thermodynamics, exergy and environmental impact". Energy Sources, 22(8), 723-732, 2000.

[2] Dincer I, Rosen MA. "Exergy as a driver for achieving sustainability". International Journal of Green Energy, 1(1), 1-19, 2004.

[3] Rakopoulos CD, Giakoumis EG. "Second law analyses applied to internal combustion engines operation". Progress in Energy Combustion Science, 32(1), 2-47, 2006.

[4] Caliskan H, Tat ME, Hepbasli A. "Performance assessment of an internal combustion engine at varying dead (reference) state temperatures". Applied Thermal Engineering, 29(16), 3431-3436, 2009.
[5] Kopac M, Kokturk L. "Determination of optimum speed of an internal combustion engine by exergy analysis". International Journal of Exergy, 2(1), 40-54, 2005.

[6] Li Y, Jia M, Chang Y, Kokjohn SL, Reitz RD. "Thermodynamic energy and exergy analysis of three different engine combustion regimes". Applied Energy, 180, 849-858, 2016.

[7] Khaliq A, Trivedi SK, Dincer I. "Investigation of a wet ethanol operated HCCI engine based on first and second law analyses". Applied Thermal Engineering, 31(10), 1621-1629, 2011.

[8] Sayin C, Hosoz M, Canakci M, Kilicaslan I. "Exergy and energy analyses of a gasoline engine". International Journal of Energy Research, 31(3), 259-273, 2007.

[9] Canakci M, Hosoz M. "Energy and exergy analyses of a diesel engine fueled with various biodiesels". Energy Sources, Part B: Economics, Planning, and Policy, 1(4), 379-394, 2006.

[10] Azoumah Y, Blin J, Daho T. "Exergy efficiency applied for the performance optimization of a direct injection compression ignition (CI) engine using biofuels". Renewable Energy, 34(6), 1494-1500, 2009.

[11] Kanoglu M, Dincer I, Rosen MA. "Exergetic performance investigation of a turbocharged stationary diesel engine". International Journal of Exergy, 5(2), 193-203, 2008.

[12] Caliskan H, Tat ME, Hepbasli A. "A review on exergetic analysis and assessment of various types of engines". International Journal of Exergy, 7(3), 287-310, 2010.

[13] Sezer I, Bilgin A. "Exergy analysis of SI engines". International Journal of Exergy, 5(2), 204-217, 2008.

[14] Ameri M, Kiaahmadi F, Khanaki M, Nazoktabar M. "Energy and exergy analyses of a spark ignition engine". International Journal of Exergy, 7(5), 547-563, 2010.

[15] Jehad AAY, Ozcan H, "Second law analysis of an LPG-powered 4-stroke SI engine under variable stroke length and compression ratio". International Journal of Exergy, 8(2), 113-127, 2011.

[16] Razmara M, Bidarvatan M, Shahbakhti M, Robinett RD. "Optimal exergy-based control of internal combustion engines". Applied Energy, 183, 1389-1403, 2016.

[17] Li Y, Jia M, Kokjohn SL, Chang Y, Reitz RD. "Comprehensive analysis of exergy destruction sources in different engine combustion regimes". Energy, 149, 697-708, 2018.

[18] Jafarmadar S. "Exergy analysis of hydrogen/diesel combustion in a dual fuel engine using three-dimensional model". International Journal of Hydrogen Energy, 39(17), 9505-9514, 2014.

[19] Paul A, Panua R, Debroy D. "An experimental study of combustion, performance, exergy and emission characteristics of a CI engine fueled by diesel-ethanolbiodiesel blends". Energy, 141, 839-852, 2017.

[20] Cengel YA, Boles MA. Thermodynamics: An Engineering Approach. $5^{\text {th }}$ ed. New York, USA, McGraw-Hill, 2006.

[21] Kotas TJ. The Exergy Method of Thermal Plant Analysis. Florida, USA, Krieger Publishing Company, 1995.

[22] Bejan A. Advanced Engineering Thermodynamics. $3^{\text {rd }}$ ed. New York, USA, John Wiley \& Sons, 2006. 